\title{
Properties and energy cost of the muscular piston pump in the suspension feeding polychaete Chaetopterus variopedatus
}

\author{
Hans Ulrik Riisgård \\ Institute of Biology, University of Odense, Campusvej 55, DK-5230 Odense M, Denmark
}

\begin{abstract}
The energetics of the muscular piston pump were studied for the filter-feeding polychaete Chaetopterus variopedatus. Agreement between clearance rates and directly measured pumping rates showed that worms transferred to glass tubes may filter at rates comparable to those of the worm in its natural tube. The respiration rate $\left(R, \mu l \mathrm{O}_{2} \mathrm{~h}^{-1}\right)$ as a function of dry weight ( $\left.\mathrm{W}, \mathrm{mg}\right)$ was: $\mathrm{R}=1.90 \mathrm{~W}^{0.59}$. Water-processing capacities of 25 to $50 \mathrm{l}$ of water filtered per $\mathrm{ml} \mathrm{O}_{2}$ consumed were found for a 'standard' $50 \mathrm{mg}$ dry weight worm pumping 150 to $300 \mu \mathrm{l}$ water $\mathrm{s}^{-1}$. The relation between imposed hydrostatic back pressure, $\Delta H_{12}$, and pumping rate, $P$, (the back pressure-pumping rate characteristic) was measured, and the maximum pressure head, $\Delta \mathrm{H}_{12}^{0}$, varied between 5 and $8.6 \mathrm{~mm} \mathrm{H}_{2} \mathrm{O}$. Video recordings were used for analysis of the pump which operated by a positive displacement pump mechanism', i.e.: $\mathrm{P}=\mathrm{A} \mathrm{f} \mathrm{L}_{\mathrm{s}}$, where $\mathrm{A}$ is the effective piston area, $\mathrm{f}=$ stroke frequency of parapods, $\mathrm{L}_{\mathrm{s}}=$ stroke length of parapods. The stroke volume of the parapods and $f$ decreased with increasing back pressures, and usually the worms responded to the imposed back pressure by reversing themselves in the glass tube. The pump pressure was expressed as: $\Delta \mathrm{H}_{\mathrm{p}}=\Delta \mathrm{H}_{\mathrm{s}}$ (system resistance) $=\Delta \mathrm{H}_{\mathrm{m}}$ (pressure loss in mucous net-bag) $+\Delta H_{k}$ (loss of kinetic energy in terminal constrictions of the tube) $+\Delta H_{i}$ (frictional resistance in tube system) $+\Delta \mathrm{H}_{12}$ (back pressure). These components were examined and the pump characteristic was approximated by the expression: $\Delta \mathrm{H}_{\mathrm{p}}=\mathrm{C}_{\mathrm{f1}} \mathrm{P}(\mathrm{f}) / \mathrm{P}_{\mathrm{o}}(\mathrm{f})+\mathrm{C}_{\mathrm{k}} \mathrm{P}(\mathrm{f})^{2}+\mathrm{C}_{\mathrm{f} 2} \mathrm{P}(\mathrm{f})+\Delta \mathrm{H}_{12}^{0}$ $\left(1-\left[P(f) / P_{0}(f)\right]^{2}\right)$, where $P_{0}(f)=A f L_{s}=\left(f / f_{\max }\right) P_{0}\left(f_{\max }\right), f_{\max }=$ maximal stroke frequency, $P_{0}\left(f_{\max }\right)=$ pumping rate capacity, $\mathrm{C}_{\mathrm{f} 1}=$ mucous bag resistance constant, $\mathrm{C}_{\mathrm{k}}=$ kinetic loss constant, $\mathrm{C}_{\mathrm{f} 2}=$ frictional coefficient. In a maximally pumping 'standard' worm, the total head loss from inlet to outlet was: $0.72 \Delta \mathrm{H}_{\mathrm{m}}+0.64 \Delta \mathrm{H}_{\mathrm{k}}+0.07 \Delta \mathrm{H}_{1}=1.43 \mathrm{~mm} \mathrm{H} \mathrm{H}_{2} \mathrm{O}$. The mechanical work done by the pump was $4.3 \mu \mathrm{W}$ (as compared to a total metabolic energy expenditure of $\mathrm{R}=107 \mu \mathrm{W}$ ). The maximal pressure rise and the total head loss in C. variopedatus are about 2 times higher than in bivalves and about 5 times higher than in ascidians. The pressure drop across the mucous net of the muscular pump of $C$. variopedatus is several times higher than across the mucous nets in ciliary pumps. The high total head loss allows $C$. variopedatus to maintain a relatively high flow velocity through a relatively small filter area.
\end{abstract}

\section{INTRODUCTION}

Suspension-feeding animals process large volumes of water for a modest yield of food. The energy cost of water processing is therefore an important bioenergetic parameter because pumping activity may consume a significant amount of metabolic energy. Suspension feeding has been thought to be an energetically marginal way of living in the sea under ordinary circumstances (Jørgensen 1966), but there is little information with which to proceed beyond this suggestion (Vogel 1981). Suspension feeders have evolved special structures to process the surrounding water and to retain small suspended food particles, mainly phytoplankton cells, but the study of the relationship between structure and mechanical performance has for a long time remained a neglected subject and is still poorly known (Jørgensen 1983).

There have only been a few earlier attempts to study and characterize the pump and filter systems of active suspension feeding animals in terms of pressures, pumping power output and energy expenditures of water processing as related to metabolic power generation. Earlier studies of the biomechanics of marine suspension-feeding animals were those of Chapman (1968) for a water-pumping worm, the echiuroid Urechis caupo, Brown $(1975,1977)$ who studied the tube-dwelling polychaete Chaetopterus variopedatus, 
and Foster-Smith (1976a, b, 1978) who measured the pressures in some ciliary filter-feeders and analysed the water flow in a number of tube-living animals. More recently the bivalve pump (Famme et al. 1986, Jørgensen et al. 1986, 1988, Clemmesen \& Jørgensen 1987, Jørgensen \& Riisgård 1988) and the ascidian pump (Riisgård 1988) have been analysed. The energetics of ciliary filter feeding in microflagellates and ciliates was elucidated by Fenchel (1980a, b, 1986).

The aim of the present work was to study the properties and energetics of the muscular piston pump of the filter-feeding polychaete Chaetopterus variopedatus, and to compare it with the recent studies of the ciliary gill pump of suspension-feeding bivalves and the ascidian ciliary pharyngeal pump.

Chaetopterus variopedatus lives in a parchment-like tube, which it secretes. The mucous-net filter feeding of this polychaete has been described, and different aspects of water pumping and particle retention have been studied (MacGinitie 1939, Wells \& Dales 1951. Jørgensen 1966, Brown 1975, 1977, Flood \& FialaMédioni 1982, Jørgensen et al. 1984). Only a short description on the feeding method, supported by Fig. $1 \mathrm{~B}$ to $\mathrm{D}$, will be given here. A flow of water current through the tube is driven in the antero-posterior direction by 3 muscular piston-like parapods in the middle region of the body (segment nos, 14,15 and 16). Two aliform notopodia (segment no. 12) continuously secrete a mucous net-bag which filters the tubal water current. The posterior end of the suspended mucous net-bag is rolled up into a food ball within the dorsal cupule, a ciliated cup-like organ (segment no. 13), and is ingested at intervals of 15 to $20 \mathrm{~min}$ (MacGinitie 1939). The mucous net is built of longitudinal parallel fibre bundles and transverse filaments forming a rectangular meshwork which efficiently retains suspended food particles down to ca $1 \mu \mathrm{m}$ (Flood \& FialaMédioni 1982).

\section{MATERIALS AND METHODS}

Chaetopterus variopedatus were collected in early August 1988 by SCUBA divers on vertical rock walls at 25 to $30 \mathrm{~m}$ water depth in the central part of the Gullmarnfjord on the Swedish west coast. The collection site and the qualitative distribution of the epifauna has recently been described by Svane \& Gröndahl (1988; Fig. 1, st. 2). The worms were taken to the nearby Kristineberg Marine Biological Station and kept in running seawater for $1 \mathrm{wk}$ before they were transported by car in an insulated and aerated seawater box to a near constant temperature room $\left(16^{\circ} \mathrm{C}\right)$ at the Biological Institute, University of Odense, Denmark. They were kept in aquaria with $31 \%$ S North Sea water. The seawater in the aquaria was changed several times a month, and fresh seawater was used in all experiments. The worms were fed a monoculture of the flagellate Dunaliella marina 3 to 5 times a week.

To allow direct measurements of pumping rates at different hydrostatic back-pressures while simultaneously recording the stroke frequency of the water pumping parapods, the worms were gently taken out of their natural leathery tube-houses and transferred to $10 \mathrm{~cm}$ long glass tubes of inner diameter comparable to that of the original tube. A $70 \mathrm{~cm}$ long silicone tube was fixed to one end of the glass tube and the specimen was gently sucked head first into the glass tube. Then the tube ends were half-closed with cleaved silicone stoppers to keep the worm inside until it had built a new thin transparent tube-house inside the glass tube. After $2 \mathrm{~d}$ the stoppers were removed, and the worm then equipped the newly secreted tube with a short narrow siphon at each end. During the first week after transfer to glass tubes 6 out of 48 specimens died (probably due to tissue injuries); but during the following period (up to $3 \mathrm{mo}$ ) only 2 of the remaining 42 individuals died.

Pumping rates of Chaetopterus variopedatus at various hydrostatic pressures imposed between the inlet and outlet end of the tube were measured by a modified version of the technique described by Famme et al. (1986; Fig. 1, alternative method a). A 51 aquarium was divided into 2 chambers $\left(C_{1}\right.$ and $\left.C_{2}\right)$ by a wall through which a $15 \mathrm{~mm}$ hole had been drilled. Into this hole was placed a silicone stopper with a hole through which the glass tube with the experimental worm was inserted (Fig. 1). A shunt connected the 2 chambers when open. The water level in the exhalant chamber $\left(\mathrm{C}_{2}\right)$ was monitored with a laser beam striking a mirror fixed to a tethered floating ping-pong ball. The mirror reflected the laser beam onto a scale about $8 \mathrm{~m}$ from the mirror. When the shunt was closed the water transport of the worm was counterbalanced by pumping equivalent volumes of water from a reservoir into $C_{1}$ and out of $\mathrm{C}_{2}$ into a measuring beaker This was done by adjusting the pump, thus maintaining the deflection of the laser at a fixed point on the scale equivalent to a known hydrostatic back pressure found as the numeric sum of the individual changes in water height in $C_{1}$ and $C_{2}$. The volume of water collected in the beaker per unit of time equalled the pumping rate of the water. A $1 \mathrm{~cm}$ movement on the scale was equivalent to $0.09 \mathrm{~mm} \mathrm{H}_{2} \mathrm{O}$ change in back pressure. Transfer of $C$. variopedatus from the holding aquarium to the apparatus for direct measurement of pumping rates disturbed it, and in many cases no pumping activity was recorded for several hours. The worm was then left in the experimental aquarium overnight prior to making measurements the next day. Fresh seawater, dim light and addition of algal cells (ca $10^{4}$ Dunaliella marina cells $\mathrm{ml}^{-1}$ ) was 
Fig. 1. (A) Experimental set-up used for direct measurement of pumping rates at different hydrostatic pressures imposed between inlet and outlet end of glass tube with Chaetopterus variopedatus inserted in the wall separating the inhalant $\left(C_{1}\right)$ and exhalant chamber $\left(C_{2}\right)$. Water level in $C_{2}$ is monitored with a laser beam striking a mirror $(\mathrm{m})$ fixed to a tethered floating pingpong ball. Pumping rate of the worm is equal to volume of water collected in the beaker (b) per unit time by means of the pump ( $p$ ) when the laser deflection point is maintained fixed on the scale. Drawing partly modified from Famme et al. (1986; Fig. 1, 'alternative method a'). (B) Lateral view of $C$. variopedatus in a glass tube lined with natural tube material. The waterpumping parapods of the 14 th, 15th and 16th segments (XIV, XV, XVI) produce a water current through the tube via the inlet and outlet terminal constrictions. Drawing based on photo from Brown (1975; Fig. 1). (C) Dorsal view of anterior end of $C$. variopedatus lodged in a glass tube. Behind the head (h) the mucous net-bag (m.b.) is stretched out between the aliform notopodia (a.n.), which secrete the mucous bag, and the dorsal cupula (d.c.) within which the mucous net is being rolled up as a food ball (f.b.). At regular intervals the worm stops pumping and contracts, and the food ball is then transported via the dorsal ciliated groove (d.g.) the mouth (m). Drawing based on macrophotography of an actively feeding specimen where the mucous bag had been visualized by staining the mucous bag with green algae introduced in the incurrent tube opening (Flood \& Fiala-Médioni 1982; Fig. 1 B). (D) Structure of mucous net of $C$. variopedatus showing a rectangular meshwork composed of an array of mostly parallel fibre bundles (fi.b.) perpendicular to an array of parallel filaments (f). Drawing based on transmission electron micrograph (8000x) of in vivo mounted mucous net (Flood \& Fiala-Médioni 1982)

adopted as a standard procedure. Individuals that had produced a new tube-house that did not fit tightly to the inner wall of the glass tube were discarded due to the possible shunt effect of back pressure water bypassing the worm.

The volume of water cleared of algal cells per unit of time, clearance, was measured in Chaetopterus variopedatus within their natural tube-houses or within the experimental glass tubes. Clearance was calculated from the rate $(\mathrm{F})$ by which Dunaliella marina cells (mean diameter $=5.6 \mu \mathrm{m}$ ) were cleared from suspensions by means of the equation: $F=(V / t) \ln \left(C_{0} / C_{t}\right)$, where $\mathrm{V}=$ volume of suspension, $\mathrm{t}=$ time, $\mathrm{C}_{0}$ and $\mathrm{C}_{\mathrm{t}}=$ algal cell concentration at time 0 and time t. Usually the individual specimens were placed in $2 \mathrm{l}$ glass beakers with a known volume of seawater with added algae to a concentration of 2 to $3 \times 10^{4}$ cells $\mathrm{ml}^{-1}$, but in one case 8 worms in their natural tubes were placed in one large aquarium with $10 \mathrm{l}$ seawater to which algal cells had been added. Adequate mixing of the suspension was ensured by aeration. Samples $(15 \mathrm{ml})$ were taken at different times from the suspension, and the algal cell concentration was determined with an electronic particle counter (Elzone model $80 \mathrm{xy}$ fitted with a $76 \mu \mathrm{m}$ orifice tube).

The oxygen consumption of 17 Chaetopterus variopedatus was measured by placing the glass tube with the worm in a test tube filled with oxygen-saturated seawater and closed with a rubber stopper, thus enclos- ing ca $30 \mathrm{ml}$ seawater without trapping air-bubbles. The pumping activity of the worm ensured mixing of the water $\left(16^{\circ} \mathrm{C}\right)$ in the respiration tube. The oxygen concentration of the water in the test tube was measured after 170 to $225 \mathrm{~min}$ with an oxygen electrode (Radiometer) mounted in a temperature constant cell. Water samples for oxygen measurements were taken in the middle of the respiration tube by means of a syringe extended with a $7 \mathrm{~cm}$ plastic tube.

A Panasonic VHS movie camera (NV-M5) was used to record stroke frequency, stroke length and stroke speed of the fan segments in 6 back pressure/pumping rate experiments. The video recordings could be analysed as single frames using a video monitor and a Panasonic AG-6200 VHS Video Cassette Recorder. Each frame represents a $40 \mathrm{~ms}$ time slice.

After the experiments the worms were taken out of their glass tubes for determination of wet weights (after 5 min drainage on filter paper) and dry weights $\left(90^{\circ} \mathrm{C}\right.$, $24 \mathrm{~h})$.

The following physical constants and conversion factors were used: kinematic viscosity $=v\left(0.011 \mathrm{~cm}^{2} \mathrm{~s}^{-1}\right)$; density of seawater $=\rho\left(1.024 \mathrm{~g} \mathrm{~cm}^{-3}\right)$; acceleration due to gravity $=g\left(980.7 \mathrm{~cm} \mathrm{~s}^{-2}\right) ; 1 \mathrm{ml} \mathrm{O}_{2} \mathrm{~h}^{-1}=$ $5333 \mu \mathrm{W}\left(1 \mathrm{ml} \mathrm{O} \mathrm{O}_{2}=1.92 \times 10^{8}\right.$ ergs $)$; dry body weight of worm $=0.2 \times$ wet weight (cf. Table 1 ). When no references are given for fluid mechanical formulars or concepts these matters may be found and explained in general textbooks (e.g. Leyton 1975, Vogel 1981). 


\section{RESULTS AND DISCUSSION}

\section{Water pumping and respiration}

If directly measured pumping rates of Chaetopterus variopedatus transferred to glass tubes are representative of pumping rates in undisturbed worms within their natural tubes, and if a normal, efficient particletrapping mucous net-bag is being produced, then clearance and pumping rate are identical. Fig. 2 shows

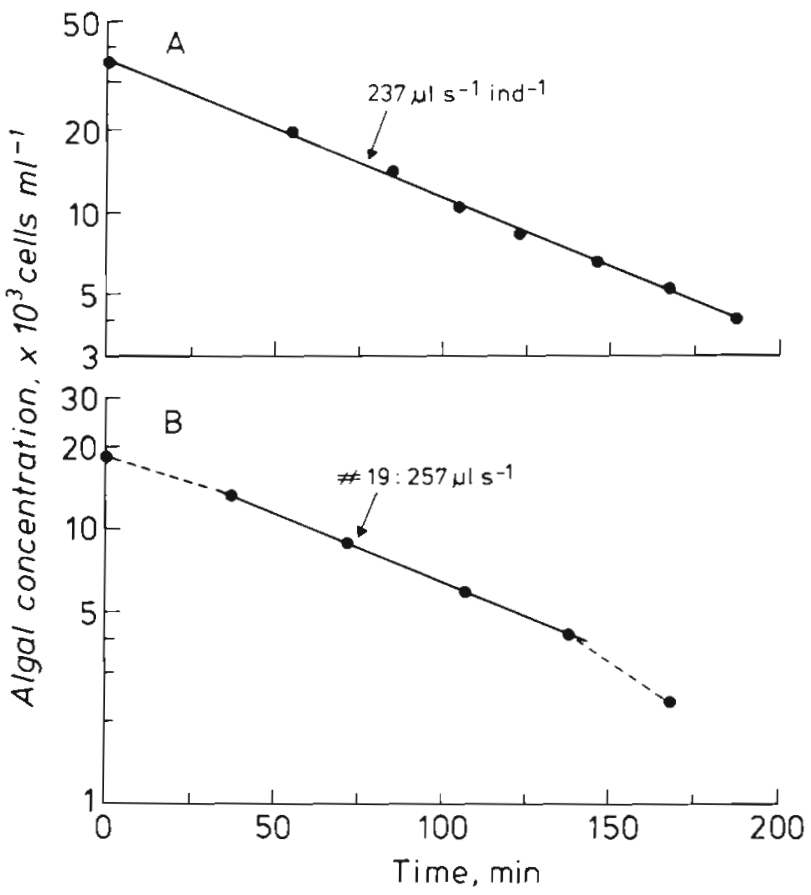

Fig. 2. Chaetopterus variopedatus. Clearance of algal cells (Dunaliella marina) in 2 experiments with $C$ variopedatus pumping in its natural tube-house. (A) Experiment with 8 worms (\# 11,12,14,15,16,17,18, 19) placed in an aquarium with 10 l seawater; (B) experiment with worm \# 19 grazing in an aquarium with $1350 \mathrm{ml}$ seawater. Pumping rates, estimated as volume of seawater cleared of algal cells per unit time, are indicated for the full drawn lines fitted by eye

clearance experiments with the worms in natural tubehouses. The mean clearance of 8 individuals was $237 \mu \mathrm{l}$ $\mathrm{s}^{-1}$, and $\mathrm{C}$. variopedatus \# 19 cleared $257 \mu \mathrm{l} \mathrm{s}{ }^{-1}$. These values may be compared to clearance rates of 107 to $340 \mu \mathrm{s} \mathrm{s}^{-1}$ measured in worms transferred to glass tubes at least 1 wk before the experiments (Fig. 3). The stroke frequency of the parapods remained nearly constant within an individual throughout an experiment (Fig. 3). The clearance experiments show that worms transferred to glass tubes may produce an efficient particleretaining mucous bag and pump water at rates comparable to those of the worm in its natural tube. This conclusion is supported by direct measurements of the pumping rates.
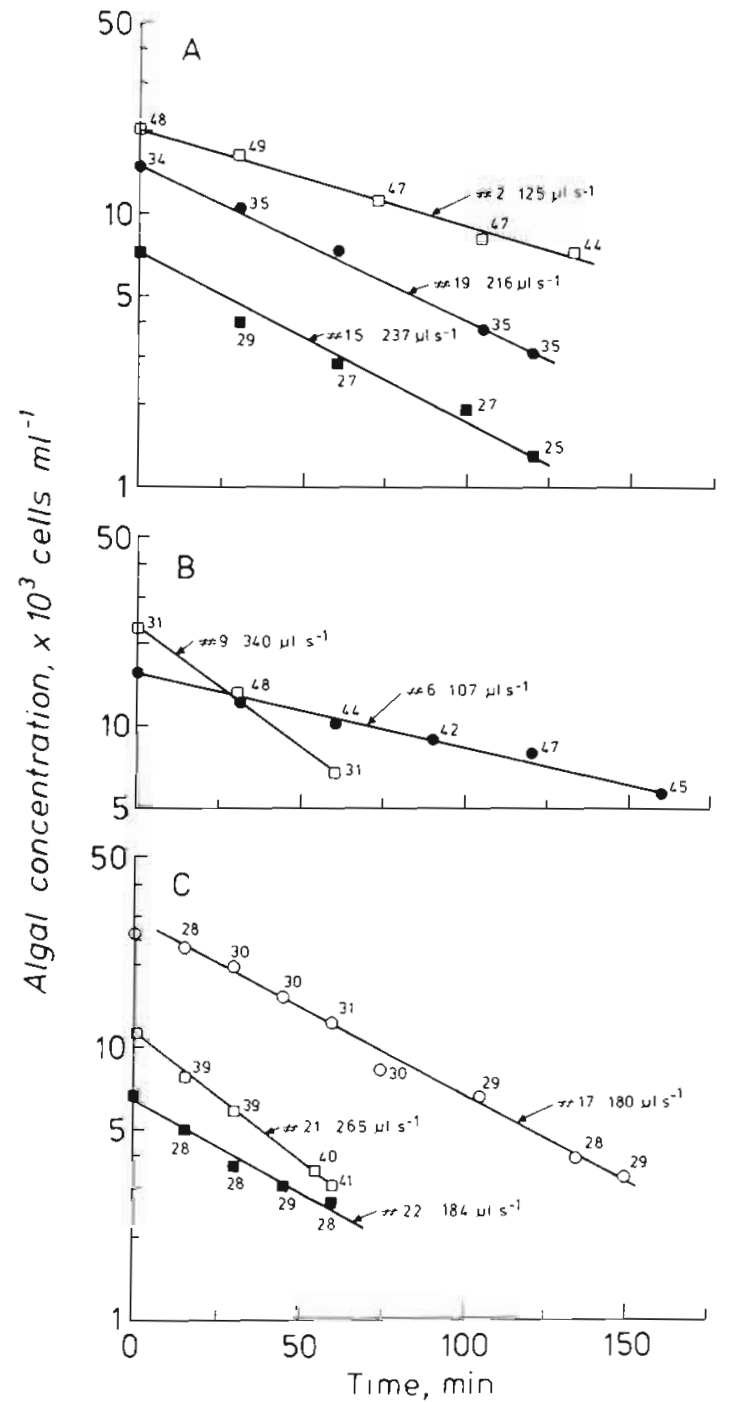

Fig. 3. Chaetopterus variopedatus. Clearance of algal cells (Dunaliella manna) in 8 experiments with $C$. variopedatus in glass tubes. Clearance is estimated as volume of water cleared of particles per unit time. Stroke frequency of the water pumping parapods (strokes $\mathrm{min}^{-1}$ ), recorded immediately before water sampling for particle counting, is indicated. Volume of seawater used in the different experiments was: $(A, B)$ $1000 \mathrm{ml}$; (C) $1500 \mathrm{ml}$

If all the water pumped through the glass tube is filtered through an intact mucous bag, which retain all particles down to about $1 \mu \mathrm{m}$ (Jørgensen et al. 1984), then the clearance rate of the nearly spherical cells of Dunaliella marina (mean diameter $=5.6 \mu \mathrm{m}$ ) should be identical to the directly measured pumping rate. Clearance values and directly measured pumping rates obtained in a number of specimens are plotted as a function of the stroke frequency of the parapods in Fig. 4. The agreement between clearance rates and pumping rates shows that Chaetopterus variopedatus transferred to glass tubes may actually produce an 
Fig. 4. Chaetopterus variopedatus. Pumping rate as a function of stroke frequency of parapods in 2 size groups of worms (A: $53 \pm 7$ SD) mg; B: $91 \pm 19 \mathrm{mg}$ ) Open symbols show indirectly measured pumping rates obtained in clearance experiments; filled symbols represent directly measured pumping rates

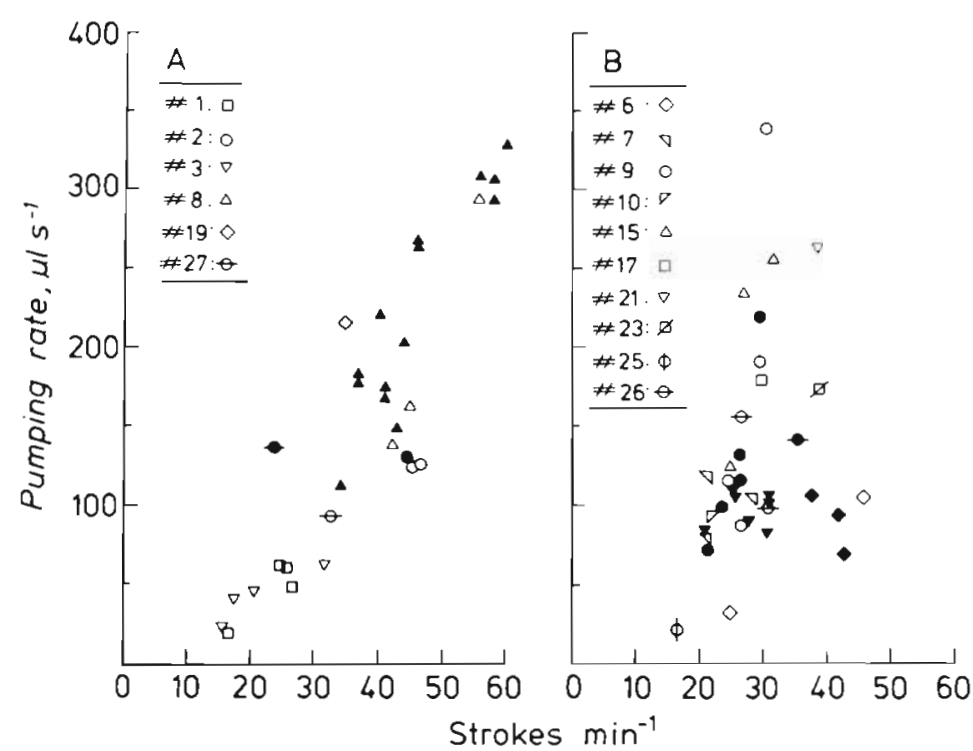

intact mucous bag through which all the water is filtered. This conclusion is supported by the frequent observation of food balls being transported from the dorsal cupula via the dorsal groove to the mouth of actively pumping worms used in the set-up for direct measurement of pumping rates.

The respiration rates measured in a number of Chaetopterus variopedatus lodged in glass tubes are shown in Table 1. The respiration rate $\left(\mathrm{R}, \mu \mathrm{O} \mathrm{O} \mathrm{h}^{-1}\right)$ as a function of dry body weight ( $\mathrm{W}, \mathrm{mg}$ ) could be expressed by the relationship: $R=1.90 \mathrm{~W}^{0.59}(r=0.689)$. The

Table 1. Chaetopterus variopedatus. Body weight and respiration rate of experimental animals transferred to glass tubes with different inner diameters (I.D.)

\begin{tabular}{|lcccc|}
\hline $\begin{array}{l}\text { Worm } \\
\#\end{array}$ & $\begin{array}{c}\text { Wet weight } \\
(\mathrm{g})\end{array}$ & $\begin{array}{c}\text { Dry weight } \\
(\mathrm{g})\end{array}$ & $\begin{array}{c}\text { I.D. } \\
(\mathrm{mm})\end{array}$ & $\begin{array}{c}\text { Respiration rate } \\
\left(\mu \mathrm{O}_{2} \mathrm{~h}^{-1}\right)\end{array}$ \\
\hline 1 & 0.441 & 0.063 & 6.7 & 19.7 \\
2 & 0.294 & 0.046 & 5.9 & 15.2 \\
3 & 0.347 & 0.044 & 6.7 & 19.5 \\
6 & 0.377 & 0.073 & 6.7 & - \\
7 & 0.485 & 0.082 & 7.5 & 20.7 \\
8 & 0.358 & 0.050 & 6.7 & 18.6 \\
9 & 0.886 & 0.129 & 8.6 & 25.7 \\
10 & 0.541 & 0.069 & 6.7 & 33.3 \\
11 & 0.517 & 0.084 & 7.4 & 31.2 \\
12 & 0.393 & 0.057 & 6.7 & 18.0 \\
14 & 0.274 & 0.045 & 6.7 & 14.9 \\
15 & 0.695 & 0.090 & 8.5 & 33.8 \\
17 & 0.598 & 0.081 & 7.5 & 23.9 \\
19 & 0.282 & 0.056 & 7.5 & - \\
21 & 0.789 & 0.119 & 7.5 & 32.2 \\
23 & 0.574 & 0.089 & 8.5 & 36.3 \\
25 & 0.626 & 0.088 & 8.5 & 23.5 \\
26 & 0.590 & 0.089 & 7.4 & 24.7 \\
27 & 0.437 & 0.058 & 6.7 & 29.5 \\
\hline
\end{tabular}

frequency of the beating fan segments varied between 12 and 30 strokes $\mathrm{min}^{-1}$ during the respiration experiments in the present work, but no differencies in respiration rate could be related to stroke frequency.

The amount of water that marine suspension feeders need to filter to obtain food enough to cover the minimal energy requirements, as assessed from rates of oxygen consumption, exceeds $10 \mathrm{l}$ of water per $\mathrm{ml}$ of oxygen consumed (Jørgensen 1975, Riisgård et al. 1980). If the pumping rate of a $50 \mathrm{mg}$ dry body weight Chaetopterus variopedatus is 150 to $300 \mu \mathrm{l} \mathrm{s}^{-1}(0.54$ to $1.08 \mathrm{l} \mathrm{h}^{-1}$ ), and the oxygen consumption (calculated from the above respiration equation) is $0.019 \mathrm{ml} \mathrm{O}_{2} \mathrm{~h}^{-1}$, water processing capacities of 25 to $50 \mathrm{l}$ of water filtered per ml of oxygen consumed are found. These water processing capacities indicate that the measured pumping rates are representative of those realized in nature.

Oxygen consumption and pumping rate measurements in Chaetopterus variopedatus have previously been published by 2 workers. Dales (1969) found that a $4.32 \mathrm{~g}$ wet weight individual pumped $0.47 \mathrm{l}$ water $\mathrm{h}^{-1}$ and consumed $0.97 \mathrm{ml} \mathrm{O}_{2} \mathrm{~h}^{-1}$ which corresponds with only $0.47 / 0.97=0.491$ of water pumped per $\mathrm{ml}$ of oxygen consumed. Brown (1977) measured the pumping rate and oxygen consumption of a mean size $4.52 \mathrm{~g}$ wet weight individual (range: 3.18 to $6.40 \mathrm{~g}$ wet wt) to be $1.94 \mathrm{l}_{\text {water }} \mathrm{h}^{-1}$ (range: 1.55 to $2.52 \mathrm{l} \mathrm{h}^{-1}$ ) and 0.56 $\mathrm{ml} \mathrm{O}_{2} \mathrm{~h}^{-1}$ (range: 0.23 to $0.90 \mathrm{ml} \mathrm{O}_{2} \mathrm{~h}^{-1}$ ), respectively, corresponding with $1.94 / 0.56=3.471$ water pumped per ml of oxygen consumed, or (at least) about 7 times lower than found in the present work. The techniques used and/or low pumping activity of the experimental worms in the 2 cited works may therefore have resulted in pumping rate estimates not being representative of 
the performance of $C$. variopedatus in nature. The same criticism seems to apply to the low filtration rates measured in C. variopedatus by Wells \& Dales (1951) and Dales $(1957,1969)$.

The oxygen consumption of a 'standard' $50 \mathrm{mg}$ dry weight worm, using the data from the above cited papers, is calculated to be 56 (Dales 1969) and $31 \mu \mathrm{O}_{2}$ $\mathrm{h}^{-1}$ (Brown 1979), which is about 2.7 and 1.5 times higher, respectively, than found in the present work. Petersen \& Johansen (1967) measured oxygen uptake as a function of oxygen tension in Mesochaetopterus taylori in which water was pumped through the tube in similar way as in Chaetopterus variopedatus. It was found that oxygen uptake dropped linearly with declining oxygen tension in the ambient water. At an oxygen tension of $120 \mathrm{~mm} \mathrm{Hg}$ the respiration rate of a $50 \mathrm{mg}$ dry weight worm is calculated to be ca 10 to $12 \mu l \mathrm{O}_{2}$ $\mathrm{h}^{-1}$ or about half the rate found for $C$. variopedatus in the present work.

An important parameter to evaluate when dealing with water pumping in Chaetopterus variopedatus is the stroke frequency of the parapods. During water pumping measurements, Brown (1977) recorded a stroke frequency varying between 27 and 40 strokes min $^{-1}$ with a mean value of 32 strokes min $^{-1}$, whereas Aksyuk \& Sveshnikov (1971) recorded 13 to 58 strokes min $^{-1}$. On successive days over a period of several weeks, MacGinitie (1939) measured the stroke frequency to be 64 and 52 strokes $\min ^{-1}$ in 2 worms. From the present study it is evident that the normal feeding behaviour of $C$. variopedatus is easily disturbed. Specimens in glass tubes were thus sensitive to sudden light-changes. The worm may react to disturbance by stopping or reducing the rate of beating of the parapods and/or contracting the body, thus reducing the stroke volume. Different degrees of disturbance may explain much of the individual variation and the broad range of stroke frequencies measured in the present study (Fig. 4).

\section{Pump characteristic}

A pump is characterized by the relation between pressure rise delivered by the pump, $\Delta \mathrm{H}_{\mathrm{p}}$, and pumping rate, $P$ (e.g. Foster-Smith 1978, Jørgensen et al. 1986). A water-pumping Chaetopterus variopedatus must generate a certain pressure to overcome the resistance to water flow. Pressure losses along the flow path are caused by frictional loss in the mucous netbag, $\Delta \mathrm{H}_{\mathrm{m}}$, the loss of kinetic energy as water enters and leaves the terminal constrictions of the tube, $\Delta \mathrm{H}_{\mathrm{k}}$ frictional resistance in the tube system, $\Delta \mathrm{H}_{\mathrm{f}}$, and back pressure, $\Delta \mathrm{H}_{12}$. At steady state, the pump pressure is equal to the system resistance: $\Delta \mathrm{H}_{\mathrm{p}}=\Delta \mathrm{H}_{\mathrm{s}}=\Delta \mathrm{H}_{\mathrm{m}}+$ $\Delta \mathrm{H}_{\mathrm{k}}+\Delta \mathrm{H}_{\mathrm{f}}+\Delta \mathrm{H}_{12}$. These components are examined below in order to determine the shape of the pump characteristic, the normal operating point (i.e. the pump head at zero back pressure) and the energetics of the pump. The pump characteristic is not directly accessible for analysis, but it may be approached indirectly through studies of the back pressure-pumping rate characteristic (Jørgensen et al. 1986).

\section{Back pressure-pumping rate characteristic}

The relation between imposed pressure, $\Delta \mathrm{H}_{12}$, and pumping rate, $P$, i.e. the back pressure-pumping rate characteristic, was measured in 6 worms (Figs. 5 and 6).

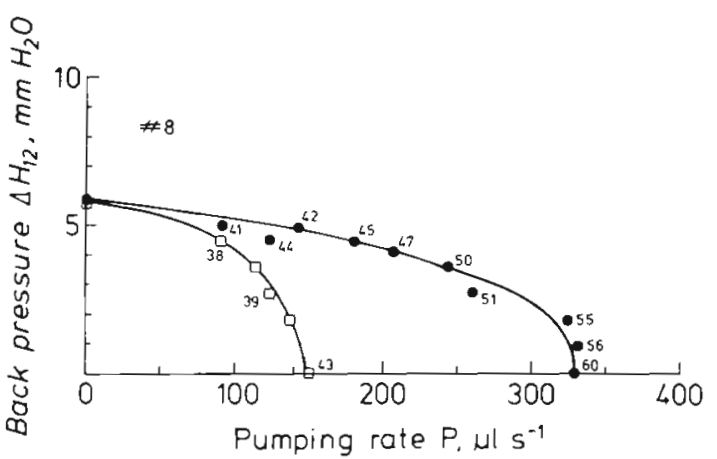

Fig. 5. Chaetopterus variopedatus. Back pressure-pumping rate characteristic in $C$. variopedatus \#8 measured in 2 experiments performed on different days on which the stroke frequency of the water pumping parapods at zero back pressure was 43 (口) and 60 ( ) strokes $\min ^{-1}$, respectively. Stroke frequency of the parapods, recorded simultaneously with direct measurement of the pumping rate at different back pressure, is indicated. Lines fitted by eye

These measurements were, however, not straightforward to perform because the worms responded to the imposed back pressure, sometimes within a few minutes, by reversing themselves in the glass tube, thus changing the direction of the water flow Table 2 lists the maximal pressure heads created by the worm and the back pressures at the time of reversal, thus terminating an experiment. A reversal in the tube was usually followed by a short period, from a few seconds up to about 1 min, of vigorous pumping activity. This irrigation behaviour seems to be similar to the normal expulsion outbursts which follow reversal under unconstrained conditions, and the function may be forcible ejection of faeces from the tube. Periodic reversal of Chaetopterus variopedatus within its tube has also been recorded by Wells \& Dales (1951). They measured pumping activity by means of an apparatus in which the worm was mounted in its own parchmentlike tube with the narrow ends cut off, and the rest tied to a rubber tubing. Due to an inserted resistance in the 
Fig. 6. Chaetopterus variopedatus. Back pressure pumping rate characteristic in 5 individuals $(\# 2,6$. $9,21,27$ ). Stroke frequency (strokes $\mathrm{min}^{-1}$ ) of the parapods, recorded simultaneously with direct measurement, is indicated. Lines fitted by eye. Worms \# 6 and \# 9 turned round in the tube at hydrostatic pressures of 2.3 and $2.7 \mathrm{~mm} \mathrm{H}_{2} \mathrm{O}$, respectively. The 2 symbols used for worm \# 21 refer to data obtained in experiments performed at a time interval of $17 \mathrm{~d}$. In the second experiment ( 1 ) the pumping rate was first measured at zero back pressure, and the worm was then allowed quickly (within about $7 \mathrm{~min}$ ) to build up the maximal back pressure, which was kept constant for several minutes before the shunt was opened. This procedure was followed 3 times; maximal back pressure measured was highest the first time and lowest the last time

Table 2. Chaetopterus variopedatus. Maximum measured back pressures at zero pumping rate, $\Delta \mathrm{H}_{12}^{0}$, and recorded back pressures at which the worm reversed itself in the glass tube, $\Delta \mathrm{H}_{\mathrm{rev}}$

\begin{tabular}{|c|c|c|}
\hline $\begin{array}{l}\text { Worm } \\
\#\end{array}$ & $\begin{array}{c}\Delta \mathrm{H}_{\mathrm{rev}} \\
\left(\mathrm{mm} \mathrm{H}_{2} \mathrm{O}\right)\end{array}$ & $\begin{array}{c}\Delta \mathrm{H}_{12}^{\mathrm{o}} \\
\left(\mathrm{mm} \mathrm{H} \mathrm{H}_{2} \mathrm{O}\right)\end{array}$ \\
\hline 2 & & 6.5 \\
\hline 6 & $2,3,3.2$ & \\
\hline 8 & $4.5,5.4,4.5,2.3,3.2$ & 5.9 \\
\hline 9 & 3.2 & \\
\hline 15 & 0.9 .5 .4 & \\
\hline 21 & $4.1,4.7,2.9,3.6,4.1$ & $7.5,8.6,6.6,5.6$ \\
\hline 26 & 2.7 & \\
\hline 27 & & 5.0 \\
\hline
\end{tabular}

tubing system (a glass tube drawn out to a jet) pumping movements of the worm caused slight variations in the seawater level in a cylinder These were recorded by means of a lever connected to a 'float'. Wells \& Dales found that periodic reversal followed by violent expulsion bursts appeared whenever the circulation in the apparatus was closed. The present work has shown that the low-pressure pump of $C$. variopedatus is very sensitive to imposed back pressures. The apparatus used by Wells \& Dales (1951) may therefore not have been appropriate due to an imposed back pressure which may affect pumping rate as well as behaviour.

From Table 2 it appears that the maximum pressure head is not well defined, but may vary between 5 and $8.6 \mathrm{~mm} \mathrm{H}_{2} \mathrm{O}$, perhaps depending on the time the worm has spent pumping against a certain back pressure (cf. Fig. 6, \# 21, triangles). The maximum pressure head does not, however, seem to be influenced by the stroke frequency of the parapods, which generally decreases
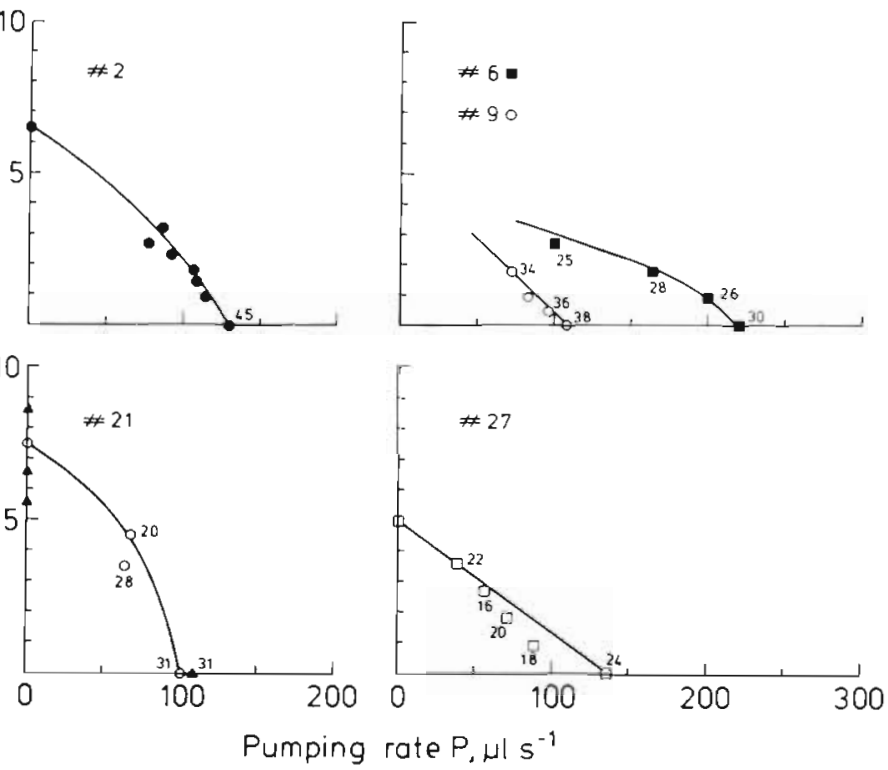

with increasing back pressure. On the basis of pumping rate and stroke frequency data measured in experiments performed on worm \# 8, the stroke volume (i.e. volume of water pumped per stroke of the parapods) could be estimated and plotted as a function of back pressure (Fig. 7). The stroke volume is only slightly influenced by back pressures up to about 3 to $4 \mathrm{~mm}$ $\mathrm{H}_{2} \mathrm{O}$, but then rapidly decreases to zero at $5.9 \mathrm{~mm} \mathrm{H}_{2} \mathrm{O}$ back pressure.

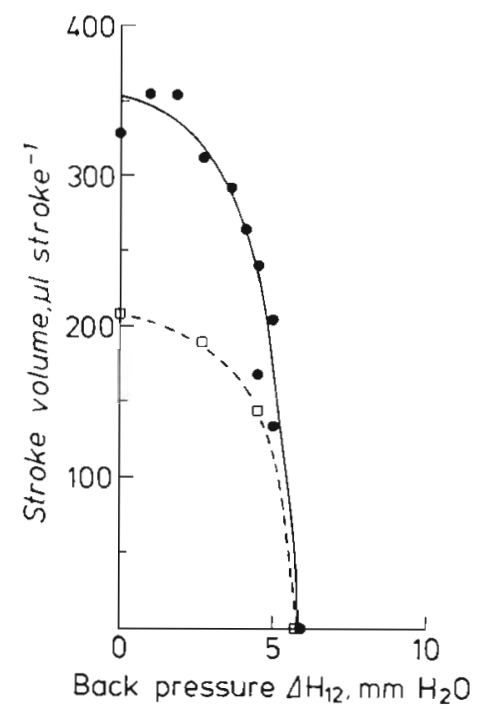

Fig. 7. Chaetopterus variopedatus. Stroke volume (i.e. volume of water pumped per stroke of the parapods), as a function of back pressure, $\Delta \mathrm{H}_{12}$, imposed between inlet und outlet end of glass tube with worm \# 8 . Stroke volume is estimated on basis of pumping rate and stroke frequency data presented in Fig. 5, and identical symbols refer to the same experiments. Stroke frequency of the parapods at zero back pressure was 60

(-) and 43 ( $\square$ ) strokes $\mathrm{min}^{-1}$, respectively 
The video recordings, originally used for measuring stroke frequencies, allowed further analysis of the pump mechanism. Worm \# 8 was video-taped during 3 direct pumping rate experiments. The pumping rate $(\mathrm{P}$, $\mu \mathrm{l} \mathrm{s}^{-1}$ ) and the stroke frequency ( $\mathrm{f}$, strokes $\mathrm{s}^{-1}$ ) in the 3 experiments were: $\mathrm{P}=329(\mathrm{f}=1), 263(0.78)$ and 221 (0.67). The stroke length $\left(\mathrm{L}_{\mathrm{s}}\right)$ of the parapods was about $6.3 \mathrm{~mm}$ (see Fig. 8A) in all cases. The pumping rate of a
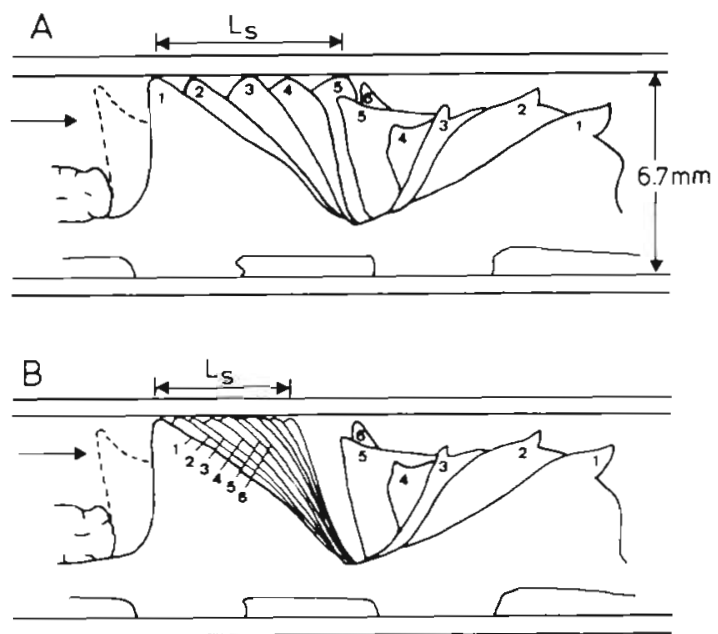

Fig. 8. Chaetopterus variopedatus. Side view of margin of pump segment 14 during power stroke and segment 15 during recovery stroke in worm \# 8 at zero (A) and $5 \mathrm{~mm} \mathrm{H}_{2} \mathrm{O}(\mathrm{B})$ back pressure. The drawing is based on video-recordings, and the shape changes of the parapods ( 1 to 6 ) have been shown at $0.16 \mathrm{~s}$ intervals ( 4 video frames). Stroke length $\left(L_{s}\right)$ and stroke speed in the power phase are reduced when a back pressure is imposed

'positive displacement pump' is characterized by the relation: $P=A f L_{s}$ where $A$ is the effective area of the piston (Wilson 1950). Because a near constant effective piston area $\left(52.2,54.2\right.$ and $52.4 \mathrm{~mm}^{2}$ ) as well as a constant stroke volume $\left(329,337\right.$ and $330 \mu$ stroke $\left.^{-1}\right)$ was found, it is reasonable to characterize the integrated 3-segment pump as a 'positive displacement pump' or a 'compound single-acting reciprocating positive-displacement pump', as suggested by Brown (1977), because more than one piston is involved (i.e. 'compound') and water is only being pumped during half the stroke cycle (i. e. 'single-acting') Due to the deformability of the pistons and their smooth serial arranged integration, such a pump yields dampened pulsations and continuous flow (Brown 1977). The reduced stroke volume (209 $\mu \mathrm{l}$ stroke $\left.{ }^{-1}\right)$ at 43 strokes min $^{-1}$ in Fig. 7 shows that the worm deviates from a mechanical pump with a constant stroke volume due to rigid pistons and a fixed stroke length. In the worm, the stroke volume decreases with contraction of the body axis, reflecting disturbance. The influence of imposed. back pressure on the pump segments was also studied by means of video recordings. The stroke length and the stroke speed of the parapods in power phase is increasingly reduced as back pressure increases (Fig. 8B). The normal intersegmental co-ordination (Berrill 1927) is disturbed because the time of the backward power phase is increased while the forward recovery phase is constant. This leads to both reduced stroke frequency and reduced stroke volume, which explains the curved shape of the back pressure-pumping rate characteristics (Figs. 5 and 6).

The following discussion considers a 'standard' Chaetopterus variopedatus (50 mg dry weight) within a $10 \mathrm{~cm}$ long glass tube $(6.7 \mathrm{~mm}$ inner diameter $)$ The pumping rate at zero back pressure is given by: $P_{0}(f)=$ A f $L_{s}=\left(f / f_{\max }\right) P_{0}\left(f_{\max }\right)$, where $\mathrm{f}_{\max }=$ maximal stroke frequency $\left(60\right.$ strokes $\left.\min ^{-1}\right)$ and $\mathrm{P}_{0}\left(\mathrm{f}_{\max }\right)=$ pumping rate capacity (300 $\mu \mathrm{l} \mathrm{s} \mathrm{s}^{-1}$ ). The back pressure-pumping rate characteristic may as a first simple approximation be expressed by the relation:

$$
\Delta \mathrm{H}_{12}=\Delta \mathrm{H}_{12}^{0}\left(1-\left[\mathrm{P}(\mathrm{f}) / \mathrm{P}_{0}(\mathrm{f})\right]^{2}\right)
$$

where $\Delta \mathrm{H}_{12}^{0}=$ the maximal pressure rise which can be delivered by the pump $\left(6 \mathrm{~mm} \mathrm{H}_{2} \mathrm{O}\right.$ in the 'standard' worm)

\section{Pressure drop across the mucous net}

The mucous net-bag of an actively feeding Chaetopterus variopedatus has been visualized by means of green algae and photographed by Flood \& Fiala-Médioni (1982). As calculated from the relative dimensions based on their photographs, the area of the mucous net-bag of a 'standard' worm is $2 \mathrm{~cm}^{2}$ (i.e. surface area of a $17 \mathrm{~mm}$ long cylinder with a diameter of $3.7 \mathrm{~mm}$ ). With a pumping rate of $300 \mu \mathrm{s}^{-1}$ the flow velocity, $\overline{\mathrm{u}}_{\text {, }}$ through the mucous net is $0.3 / 2=0.15 \mathrm{~cm} \mathrm{~s}^{-1}$.

The fine structure of the mucous nets has been studied by Flood \& Fiala-Médioni (1982), using transmission electron microscopy with samples of the nets mounted on grids during in vivo conditions (i.e. the nets were unfixed when mounted). According to the authors, this should have prevented pronounced shrinkage during dehydration and drying. The mucous net was found to be a rectangular meshwork consisting of one array of mostly parallel fibre bundles, composed of 3 to 10 fibres, with a spacing of $0.75 \pm 0.96 \mu \mathrm{m}$ in one direction and perpendicular to this system a second array of parallel filaments spaced by relatively constant intervals of $0.46 \pm 0.12 \mu \mathrm{m}$ (Fig. 1D). Each fibre bundle was about 0.1 um thick and the filaments were ranging in diameter between 10 to $30 \mathrm{~nm}$. A pore width somewhat below $0.5 \mu \mathrm{m}$ is thus suggested. However, the particle retention spectrum measured by Jørgensen et 
al. (1984) suggests a $3 \times$ larger mesh size (i.e. $2.28 \times$ $1.38 \mu \mathrm{m}$ ) because only particles down to about $1.5 \mu \mathrm{m}$ are retained with $100 \%$ efficiency. The exact mesh size of the mucous net is thus somewhat obscure. The pressure drop across filters, such as the mucous net, may be estimated from the modified Tamada-Fujikawa equation (Silvester 1983):

$$
\Delta H=v \bar{u} 8 \pi / h_{e} \Lambda_{e} g
$$

where $h_{e}=h_{1} h_{2} /\left(h_{1}+h_{2}\right) ; h_{1}=$ width of mesh; $h_{2}=$ length of mesh; $\Lambda_{e}=1-2 \ln \tau+r^{2} / 6 ; \tau=d / h_{0} ; h_{0}=$ $\mathrm{h}_{1} \mathrm{~h}_{2} / \sqrt{\mathrm{h}_{1}^{2}+\mathrm{h}_{2}^{2}} ; \mathrm{d}=$ diameter of cylindrical fibre.

Estimated pressure drops across the mucous filter as a function of filament diameter using the mean mesh dimensions $(0.76 \times 0.46 \mu \mathrm{m})$ suggested by Flood \& Fiala-Médioni (1982) and the $3 \times$ larger dimensions $(2.28 \times 1.38 \mu \mathrm{m})$ suggested by the retention efficiency measured by Jorgensen et al. (1984) are shown in Fig. 9. The pressure drop across the net with a mesh

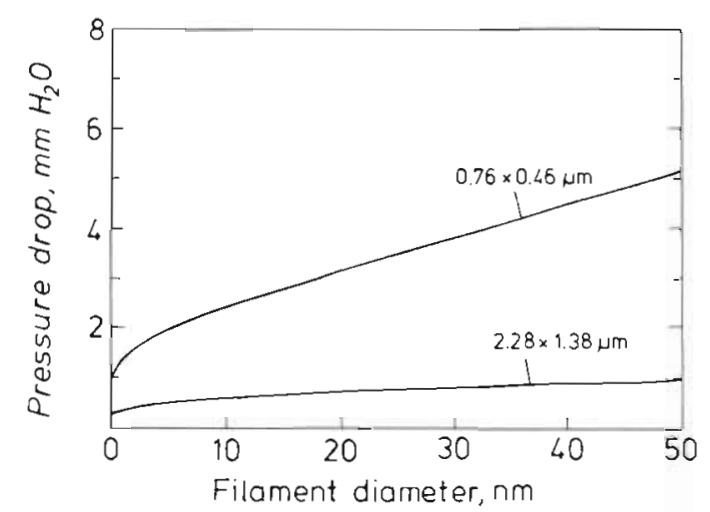

Fig. 9. Chaetopterus variopedatus. Estimated pressure drop across the mucous net-bag as a function of filament diameter in a 'standard' $50 \mathrm{mg}$ dry weight worm pumping $300 \mu \mathrm{l} \mathrm{s}^{-1}$ (flow speed through the net $=0.15 \mathrm{~cm} \mathrm{~s}^{-1}$ ). The mucous net has been considered to be a rectangular mesh, composed of 2 parallel-cylinder filters, of different possible spacings: $0.76 \times 0.46$ and $2.28 \times 1.38 \mu \mathrm{m}$. crossing each other at right angles. In this study a mean filament diameter of $20 \mathrm{~nm}$ and a mesh size of $2.28 \times 1.38 \mu \mathrm{m}$ is suggested to be representative of the in vivo dimensions

size of $2.28 \times 1.38 \mu \mathrm{m}$ is only little affected by the filament diameter, and if a mean filament diameter of $20 \mathrm{~nm}$ is assumed to be representative of the in vivo situation, a pressure drop of $0.72 \mathrm{~mm} \mathrm{H}_{2} \mathrm{O}$ is found. The filter resistance has previously been calculated to 0.7 $\mathrm{mm} \mathrm{H}_{2} \mathrm{O}$ in Chaetopterus variopedatus by Jørgensen et al. (1984) by means of another formula and assuming a mesh size of $1.7 \mu \mathrm{m}$. In mucous-net feeders that use cilia for generating the water current, the pressure drop across the filter is lower, e.g. $0.2 \mathrm{~mm} \mathrm{H}_{2} \mathrm{O}$ in the gastropod Crepidula fornicata and $0.1 \mathrm{~mm} \mathrm{H}_{2} \mathrm{O}$ in the ascidian Ascidia mentula (Jørgensen et al. 1984). The pressure drop in the ascidian Styela clava has previously been estimated by the present author (Riisgård 1988), using the same formula as in the present paper, but the data need to be corrected as follows: The retention efficiency spectrum measured in S. clava by Jørgensen et al. (1984) suggests $4 \times$ larger net dimensions (i.e. $1.4 \times 5.4 \mu \mathrm{m}$ ) than the general mean value reported for ascidians by Flood \& Fiala-Médioni (1981). Using net dimensions of $1.4 \times 5.4 \mu \mathrm{m}$, pressure drops of 0.11 to $0.13 \mathrm{~mm} \mathrm{H}_{2} \mathrm{O}$ are found for filament diameters between 20 to $40 \mathrm{~nm}$. The rough estimates available thus suggest that the pressure drop across the mucous net of the muscular pump of $C$. variopedatus is several times higher than that across the mucous nets in ciliary pumps.

Because the pressure drop across the mucous net is directly proportional to the flow velocity of water through the net this component of the system resistance may be expressed as:

$$
\Delta H_{m}=C_{f 1} P(f) / P_{0}(f)
$$

where $\mathrm{C}_{\mathrm{fl}}=0.72 \mathrm{~mm} \mathrm{H}_{2} \mathrm{O}$ when the pumping rate capacity of the Chaetopterus variopedatus is fully exploited.

\section{Kinetic and irictional loss}

The pressure resistance due to kinetic loss in a constriction is given by: $v^{2} / 2 g$, where $v$ is the water velocity and $g$ the acceleration due to gravity. The total kinetic loss in the 2 constrictions of the worm tube is therefore given by: $\Delta H_{k}=v^{2} / g$. Because $v=P(f) / A$, where $A$ is the cross sectional area of the inlet and outlet opening, the relation may be written as:

$$
\Delta \mathrm{H}_{\mathrm{k}}=\mathrm{C}_{\mathrm{k}} \mathrm{P}(\mathrm{f})^{2}
$$

where $C_{k}=\left(g A^{2}\right)^{-1}$. It is seen that the relative importance of the kinetic loss increases with the pumping rate because $\Delta H_{k}$ is a quadratic function of $P(f)$. When exploiting its water pumping capacity the 'standard' worm pumps $300 \mu \mathrm{l}$ water $\mathrm{s}^{-1}$ through a $10 \mathrm{~cm}$ long tube (inner diameter $=6.7 \mathrm{~mm}$ ) with 2 terminal circular constrictions (diameter $=2.2 \mathrm{~mm}$ ). The velocity at the inlet and outlet opening is: $v=0.3 /\left(\pi 0.11^{2}\right)=7.89 \mathrm{~cm}$ $\mathrm{s}^{-1}$, and the total kinetic loss in the 2 constrictions is thus $\Delta \mathrm{H}_{\mathrm{k}}=\mathrm{v}^{2} / \mathrm{g}=0.64 \mathrm{~mm} \mathrm{H}_{2} \mathrm{O}$.

The geometry of the tube with a pumping worm inside is not appropriate for an estimate to be made of frictional loss. But to arrive at an estimate of the order of magnitude the tube may be considered 'empty'. The velocity in the tube (length $\mathrm{L}=10 \mathrm{~cm}$; radius $\mathrm{I}=$ $0.335 \mathrm{~cm})$ is $\mathrm{v}_{\mathrm{t}}=0.3 /\left(\pi 0.335^{2}\right)=0.85 \mathrm{~cm} \mathrm{~s}^{-1}$, and the Reynolds number is $\operatorname{Re}=2 \mathrm{r} v_{t} / v=52$ (laminar flow). The entrance length is: $0.058 \operatorname{Re} 2 \mathrm{r}=2.0 \mathrm{~cm}$, and the 
Poiseuille's equation may therefore be used to give an estimate of the pressure drop in the tube. The PoiseuilIe's equation may in this case be written as:

$$
\Delta \mathrm{H}_{\mathrm{f}}=8 \mathrm{P}_{0}(\mathrm{f}) v \mathrm{~L} / \pi \mathrm{r}^{4} \mathrm{~g}
$$

providing a frictional loss in the tube of $0.07 \mathrm{~mm} \mathrm{H}_{2} \mathrm{O}$. Because the flow is laminar the frictional loss in the tube is a linear function of the flow rate, that is:

$$
\Delta \mathrm{H}_{\mathrm{f}}=\mathrm{C}_{\mathrm{f} 2} \mathrm{P}(\mathrm{f})
$$

where $\mathrm{C}_{\mathrm{f} 2}$ is the frictional coefficient defined as the slope of $\Delta \mathrm{H}_{\mathrm{f}}$ versus $\mathrm{P}(\mathrm{f})$.

\section{Shape of pump characteristic and power curve}

In a maximally pumping 'standard' Chaetopterus variopedatus the total head loss along the flow path from inlet to outlet (i.e. the normal operating point $O_{p}$ ) has until now been estimated to be: $0.72 \Delta \mathrm{H}_{\mathrm{m}}+0.64 \Delta \mathrm{H}_{\mathrm{k}}+$ $0.07 \Delta \mathrm{H}_{\mathrm{f}}=1.43 \mathrm{~mm} \mathrm{H} \mathrm{H}_{2} \mathrm{O}$. Brown (1977) measured the discharge pressure in $C$. variopedatus not secreting the feeding bag and found that the pressure varied in a pulsatile fashion between 1 and $2 \mathrm{~mm} \mathrm{H}_{2} \mathrm{O}$. This value falls within the range of the sum of estimated mucous bag and exit head loss in the present work

If one knows the expressions of the different components in the system resistance, the pump characteristic may be approximated by the expression: $\Delta \mathrm{H}_{\mathrm{p}}=\Delta \mathrm{H}_{\mathrm{m}}+$ $\Delta \mathrm{H}_{\mathrm{k}}+\Delta \mathrm{H}_{\mathrm{f}}+\Delta \mathrm{H}_{12}$ or:

$$
\begin{gathered}
\Delta \mathrm{H}_{\mathrm{p}}=\mathrm{C}_{\mathrm{f} 1} \mathrm{P}(\mathrm{f}) / \mathrm{P}_{0}(\mathrm{f})+\mathrm{C}_{\mathrm{k}} \mathrm{P}(\mathrm{f})^{2}+\mathrm{C}_{\mathrm{f} 2} \mathrm{P}(\mathrm{f})+ \\
\Delta \mathrm{H}_{12}^{0}\left(1-\left[\mathrm{P}(\mathrm{f}) / \mathrm{P}_{0}(\mathrm{f})\right]^{2}\right)
\end{gathered}
$$

Further, the power output $\left(\mathrm{P}_{\mathrm{p}}\right)$ from the pump can be calculated as pumping pressure $\left(\Delta \mathrm{P}=\rho g \Delta \mathrm{H}_{\mathrm{p}}\right)$ times pumping rate:

$$
\mathrm{P}_{\mathrm{p}}=\rho g \Delta \mathrm{H}_{\mathrm{p}} \mathrm{P}(\mathrm{f})
$$

The curves for the different equations (1) to (7) are shown in Fig. 10.

The work done by the pump may be compared to the total metabolic energy expenditure of the 'standard' Chaetopterus variopedatus, as expressed by the rate of oxygen consumption $\mathrm{R}=0.02 \mathrm{ml} \mathrm{O} \mathrm{h}^{-1}$ which corresponds to $107 \mu \mathrm{W}$. At $\Delta \mathrm{H}_{\mathrm{p}}=\mathrm{O}_{\mathrm{p}}=1.43 \mathrm{~mm} \mathrm{H}_{2} \mathrm{O}$ the pumping power $P_{p}=4.3 \mu \mathrm{W}$. Thus, the mechanical work done by the pump (i.e. pump output) constitutes $(4.3 / 107) 100=4 \%$ of the total metabolic rate.

The muscular pump of Chaetopterus variopedatus may be compared to the ciliary pumps of suspensionfeeding bivalves (Jørgensen et al. 1986, 1988, Jørgensen \& Riisgărd 1988) and ascidians (Riisgård 1988). The normal operating point was about $1 \mathrm{~mm} \mathrm{H}_{2} \mathrm{O}$ in bivalves (Jørgensen et al. 1988) and about 0.3 in ascidians. The back pressure-pumping rate characteristics were linear

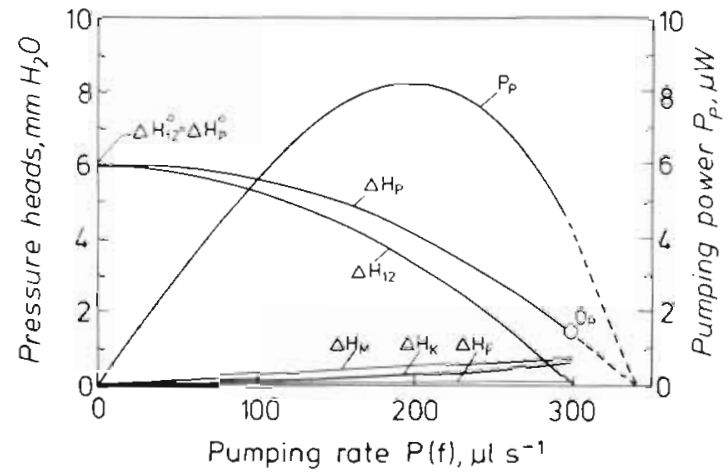

Fig. 10. Chaetopterus variopedatus. Pressure head-pumping rate characteristics for pump pressure $\left(\Delta \mathrm{H}_{\mathrm{p}}\right)$ and the different components in the system resistance: mucous bag $\left(\Delta \mathrm{H}_{\mathrm{M}}\right)$, kinetic loss $\left(\Delta \mathrm{H}_{K}\right)$, friction $\left(\Delta \mathrm{H}_{\mathrm{F}}\right)$ and back pressure $\left(\Delta \mathrm{H}_{12}\right)$. $\mathrm{P}$ : pumping rate-pumping power characteristic of the pump: $O_{p}$ : normal operating point (i.e. the pump head at zero back pressure). Calculations are based on a 'standard' worm exploiting its water pumping capacity $\left(\mathrm{P}_{\mathrm{o}}\left(\mathrm{f}_{\max }\right)=300 \mu \mathrm{l} \mathrm{s}{ }^{-1}\right)$; see text for further explanation

in both bivalves and ascidians, and the maximum pressures about $3.5 \mathrm{~mm} \mathrm{H}_{2} \mathrm{O}$ and $1.2 \mathrm{~mm} \mathrm{H}_{2} \mathrm{O}$, respectively. The metabolic to mechanical efficiency of the bivalve gill pump was studied by Clemmesen \& Jørgensen (1987) who based their estimates on measurements of the relation between beat frequency of the lateral cilia and oxygen consumption of gill fragments. They found that the metabolic rate of the cells carrying the water pumping lateral cilia in a $35 \mathrm{~mm}$ long 'standard' Mytilus edulis amounted to $78 \mu \mathrm{W}$, and the power output from the pump was estimated to $14 \mu \mathrm{W}$ at a pressure of $1.4 \mathrm{~mm} \mathrm{H}_{2} \mathrm{O}$. Thus the mechanical pumping power as a percentage of the power generation of the lateral cilia was $(14 / 78) 100=18 \%$. Adopting $1.0 \mathrm{~mm} \mathrm{H} \mathrm{H}_{2} \mathrm{O}$ and not $1.4 \mathrm{~mm} \mathrm{H}_{2} \mathrm{O}$ as the operating pressure in the 'standard' mussel (Jørgensen et al. 1988) this provides a somewhat lower metabolic to mechanical efficiency of (10/78)100 $=13 \%$

The total metabolic rate of the standard $35 \mathrm{~mm}$ mussel is about $900 \mu \mathrm{W}$ (Jørgensen et al. 1986) and the power generation of the lateral cilia amounts to about $(78 / 900) 100=8.7 \%$ of the total metabolic energy expenditure. The power output of the bivalve pump is found to be about $(10 / 900) 100=1.1 \%$ of the total energy expenditure. In ascidians the value is 0.1 to $0.2 \%$ (Riisgård 1988) which may be compared to about $4 \%$ found for Chaetopterus variopedatus in the present work. The efficiency of metabolic to mechanical power output from the Chaetopterus pump is unknown, but the efficiency of muscular work may be higher than found for ciliary work in bivalves. The percentage of metabolic power used for water processing in suspension-feeding metazoans may thus very well be found to be about 2 to $20 \%$. 
The maximal pressure rise and the normal operating point in Chaetopterus variopedatus seem to be about 2 times higher than in bivalves and substantially higher than in ascidians. Both $C$. variopedatus and ascidians use a mucous net for trapping food particles, and it seems reasonable to suggest that the total mucous net area, the mesh size and the velocity of water through the net have been dimensioned in such a way that the resulting pressure drop makes up a relatively low percentage (20 to $30 \%$ ) of the maximal pressure rise which can be delivered by the pump. Flow velocities through ascidian mucous nets have been estimated to be $0.3 \mathrm{~mm} \mathrm{~s}^{-1}$ in Styela clava (Riisgård 1988), $0.4 \mathrm{~mm}$ $\mathrm{s}^{-1}$ in Ascidia mentula (Jørgensen et al. 1984) and $0.2 \mathrm{~mm} \mathrm{~s}^{-1}$ in Ciona intestinalis (Jørgensen 1983). These values may be compared to $1.5 \mathrm{~mm} \mathrm{~s}^{-1}$ in $C$. variopedatus in the present study. The about 5 times larger operating point compared to ascidians allows $C$. variopedatus to maintain an about 5 times higher flow velocity and thus to produce a mucous net with an about 5 times smaller area.

The respiration rate of Chaetopterus variopedatus measured in the present work may also be compared to suspension-feeding polychaetes which use cilia to generate a feeding current. Kayar (1978) and Mynster Ivarsson (unpubl.) measured the oxygen uptake in Sabella melanostrigma and $S$. penicillus, respectively. By converting wet body weight to dry weight Kayar's data conform to the following equation for respiration $\left(\mathrm{R}, \mathrm{ml} \mathrm{O}_{2} \mathrm{~h}^{-1}\right)$ as a function of dry weight $(\mathrm{W}, \mathrm{g}): \mathrm{R}=$ $0.38 \mathrm{~W}^{1.02}$ (W interval: 2 to $160 \mathrm{mg}$ ), and the respiration rate of a $50 \mathrm{mg}$ dry weight worm is found to be $17.9 \mu \mathrm{l}$ $\mathrm{O}_{2} \mathrm{~h}^{-1}$. A similar estimate using the data of Mynster Ivarsson: $\mathrm{R}=0.12 \mathrm{~W}^{0.66}(\mathrm{r}=0.98, \mathrm{~W}$ interval: 3.5 to $122 \mathrm{mg}$ ) results in a respiration rate of $16.6 \mu \mathrm{l} \mathrm{O} \mathrm{h}^{-1}$. These respiration rates are close to $20 \mu \mathrm{l} \mathrm{O} \mathrm{O}_{2} \mathrm{~h}^{-1}$ used for a 'standard' $C$. variopedatus in the present work. This indicates that the energy costs of water pumping by means of muscular power in C. variopedatus may be comparable to the energy expenditures of water processing by means of cilia in Sabella spp. and other metazoan suspension feeders. This conclusion is in agreement with the fact that several members of the suspension feeding family Chaetopteridae use the beating of ciliary membranelles to drive water through one or several mucous net-bags straining the tubal water current (Barnes 1965). A larger mucous net area and consequently a lower pump pressure than obtaining in $C$. variopedatus may, however, be expected to be found in chaetopterid polychaetes using cilia to generate the feeding current because the muscular generation of the tubal water current in $C$. variopedatus may allow this worm to sustain a higher pump pressure than can ciliary feeders.

The above considerations may be extended to sus- pension feeding ciliates which retain particles by sieving the feeding currents through ciliary organelles (Fenchel 1980a, b, 1986). Ciliates and other protozoa spend a very small fraction of the total energy expenditure on mechanical work. The energetics of the suspension-feeding ciliate Cyclidium sp. (length ca $35 \mu \mathrm{m}$ ) were elucidated by Fenchel (1986). The water velocity through the ciliary filter (i.e. the paroral membrane consisting of a single row of parallel cilia with a free space between them of about $0.3 \mu \mathrm{m}$ ) was $0.025 \mathrm{~mm}$ $\mathrm{s}^{-1}$, and the pressure drop across the filter was estimated to $0.16 \mathrm{~mm} \mathrm{H}_{2} \mathrm{O}$ by means of the TamadaFujikawa equation. The pumping power of Cyclidium amounted to only $0.003 \%$ of the total metabolic energy expenditure. With the conservative estimate of $1 \%$ efficiency in the conversion of chemical work to mechanical work, Fenchel concluded that the ciliate would only spend about $0.3 \%$ of its power generation on the filtration of food particles. From the data given in the present paper it appears that the 'pump work', i.e. pumping power expressed as percentage of total power generation $\left(\mathrm{P}_{\mathrm{p}} / \mathrm{R}\right)$, in metazoan filter feeders may be 2 to 3 orders of magnitude higher than in ciliates and other suspension-feeding protozoa. This difference is probably due to a very high weight-specific metabolic rate as related to high specific growth rate in protozoans in which most of the energy is spent on growth (i.e. synthesis of macromulecules; Fenchel 1986). Finally, it should be mentioned that the more than 50 times lower flow velocity in Cyclidium compared to Chaetopterus variopedatus $(1.5 / 0.025=60)$ is correlated with an about 5 times higher retention efficiency $(1.3 / 0.3=4.6)$ and an about 10 times lower operating point $(1.43 / 0.16=8.9)$ in the ciliate.

Acknowledgements. Thanks are due to Prof. P. Schell Larsen, Fluid Mechanical Department, Technical University of Denmark, for his valuable comments. I am grateful to Prof. C. Barker Jorgensen, August Krogh Institute, University of Copenhagen, and Drs T. Forbes and E. Kristensen at this institute for critically reading the manuscript. During a pilot study in June 1988 I stayed at the Kristineberg Marine Biological Station, Sweden, and I am grateful to the Station and especially to I. Svane and B. Bergstrom who carried out the SCUBA diving.

\section{LITERATURE CITED}

Aksyuk, T. S., Sveshnikov, V. A. (1971). A plunger mechanism for expulsion of water in Chaetopterus variopedatus (Polychaeta, Annelida). Dokl. Akad. Nauk. SSSR Biol. Sci. (Engl. Transl.) 197: 285-288

Barnes, R. D. (1965). Tube-building and feeding in Chaetopterid polychaetes. Biol. Bull mar biol. Lab., Woods Hole 129: 217-233

Berrill, N. J. (1927). The control of the beat of the fan segments in Chaetopterus variopedatus. Nature, Lond. 119: 564-565 Brown, S. C. (1975). Biomechanics of water-pumping by 
Chaetopterus variopedatus Renier. Skeletomusculature and kinematics. Biol. Bull. mar. biol. Lab., Woods Hole 149: $136-150$

Brown, S. C (1977). Biomechanics of water-pumping by Chaetopterus variopedatus Renier: kinetics and hydrodynamics. Biol. Bull. mar biol. Lab., Woods Hole 153: $121-132$

Chapman, G. (1968). The hydraulic system of Urechis caupo Fisher \& MacGinitie. J. exp. Biol. 49: 657-667

Clemmesen, B., Jørgensen, C. B. (1987). Energetic costs and efficiencies of ciliary filter feeding. Mar. Biol. 94: 445-449

Dales, R. P. (1957). Some quantitative aspects of feeding in sabellid and serpulid fan worms. J. mar. biol. Ass. U.K. 36: 309-316

Dales, R. P. (1969). Respiration and energy metabolism in annelids. In: Florking, M., Scheer, B. T. (eds.) Chemical zoology, Vol. IV Academic Press, New York, p. 93-109

Famme, P., Riisgård, H. U., Jørgensen, C. B. \{1986\}. On direct measurement of pumping rates in the mussel Mytilus edulis. Mar. Biol. 92: 323-327

Fenchel, T. (1980a). Suspension feeding in ciliated protozoa: Structure and function of feeding organelles. Arch. Protistenk. 123: 239-260

Fenchel, T (1980b). Relation between particle size selection and clearance in suspension-feeding ciliates. Limnol. Oceanogr. 25: 733-738

Fenchel, T. (1986). Protozoan filter feeding. Prog. Protistol. 1 65-113

Flood, P. R., Fiala-Médioni, A. (1981). Ultrastructure and histochemistry of the branchial sac of benthic filter-feeding invertebrates (Ascidians). Acta zool., Stockh. 59: 1-9

Flood, P. R., Fiala-Médioni, A. (1982). Structure of the mucous feeding filter of Chaetopterus variopedatus (Polychaeta). Mar. Biol. 72: 27-33

Foster-Smith, R. L. (1976a). Some mechanisms for the control of pumping activity in bivalves. Mar. Behav. Physiol. 4: 41-60

Foster-Smith, R. L. (1976b). Pressures generated by the pumping mechanism of some ciliary filter-feeders. J. exp. mar. Biol. Ecol. 25: 199-206

Foster-Smith, R. L. (1978). An analysis of water flow in tubeliving animals. J. exp. mar Biol. Ecol. 34: 73-95

Jørgensen, C. B. (1966). Biology of suspension feeding. Pergamon Press, Oxford

Jørgensen, C. B. (1975). Comparative physiology of suspension feeding. Ann. Rev. Physiol 30: 391-454

This article was submitted to the editor
Jorgensen, C. B. (1983). Fluid mechanical aspects of suspension feeding. Mar Ecol. Prog. Ser 11: 89-103

Jørgensen, C. B., Famme, P., Saustrup Kristensen, H., Larsen, P. S., Møhlenberg, F., Riisgård, H. U. (1986). The bivalve pump. Mar Ecol. Prog. Ser. 34: 69-77

Jørgensen, C. B., Kiørboe, T., Møhlenberg, F., Riisgård, H. U. (1984). Ciliary and mucus-net filter feeding, with special reference to fluid mechanical characteristics. Mar Ecol. Prog. Ser 15: 283-292

Jørgensen, C. B., Larsen, P. S., Møhlenberg, F., Riisgård, H. U. (1988). The mussel pump: properties and modelling. Mar Ecol. Prog. Ser. 45: 205-216

Jørgensen, C. B., Riisgård, H. U. (1988). Gill pump characteristics of the soft clam Mya arenaria. Mar. Biol. 99: 107-109

Kayar, S. R. (1978). Oxygen uptake and the role of chlorocruorin in Sabella melanostigma (Polychaeta: Sabellidae). Ph.D. thesis, University of Miami. University Microfilms International No.: 7818711

Leyton, L. (1975). Fluid behaviour in biological systems. Clarendon Press, Oxford

MacGinitie, G. E. (1939). The method of feeding of Chaetopterus. Biol. Bull. mar. biol. Lab., Woods Hole 77: 115-188

Petersen, J. A., Johansen, K. (1967). Aspects of oxygen uptake in Mesochaetopterus taylori, a tube-dwelling polychaete Biol. Bull. mar. biol. Lab., Woods Hole 133: 600-605

Riisgård, H. U. (1988). The ascidian pump: properties and energy cost. Mar Ecol. Prog. Ser. 47. 129-134

Riisgård, H. U., Randløv, A., Kristensen, P. S. (1980). Rates of water processing, oxygen consumption and efficiency of particle retention in veligers and young post-metamorphic Mytilus edulis. Ophelia 19: 37-47

Silvester, N. R. (1983). Some hydrodynamic aspects of filter feeding with rectangular-mesh nets. J. theor. Biol. 103: $265-286$

Svane, I., Gröndahl, F. (1988). Epibioses of Gullmarsfjorden an underwater stereophotographical transect analysis in comparison with the investigations of Gislen in 1926-1929. Ophelia 28: 95-110

Vogel, S. (1981). Life in moving fluids. The physical biology of flow. Princeton University Press, New Jersey

Wells, G. P., Dales, R. P. (1951). Spontaneous activity patterns in animal behaviour: the irrigation of the burrow in the polychaetes Chaetopterus variopedatus Renier and Nereis diversicolor O. F. Müller. J. mar. biol. Ass. U.K. 29: 661-680

Wilson, W E. (1950). Positive-displacement pumps and fluid motors. Pitman, New York

Manuscript first received: March 10,1989

Revised version accepted: May 30, 1989 